\title{
The Analysis of Current Research Situation and Development Trend for College English Writing
}$$
\text { Yi Lu, a and Mu Sun }{ }^{2, b}
$$ \\ ${ }^{1}$ Jilin Business and Technology College, No.1666 Calun Lake Street, Changchun, Jilin Province, \\ China \\ ${ }^{2}$ Changchun University of Science and Technology, No.7089 Weixing Road, Changchun, Jilin \\ Province, China

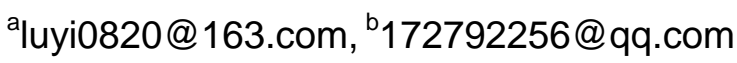

Keywords: English writing teaching; Current situation; Trend; Research

\begin{abstract}
This paper takes the college English writings collected on CNKI as sources, and investigates the research papers about college English writing from eight key periodicals on foreign language study. The study aims are to state the research situations about college English writing, and discuss the problems which mainly existed in the research objects and teaching materials. After analyzing problems, it tries to give solutions, such as, we need more studies on online writing, on enriching writing contents, and on creative teaching models, etc. At last, the paper discusses the development trend for college English writing research.
\end{abstract}

\section{Introduction}

English writing is an output skill, and it reflects the comprehensive abilities of English learners. [1] English writing is also a mind coding process, and it is the same as oral English in nature, because oral English activities need mind coding as well. Therefore, writing practice is helpful to the increase of speaking skills, and it also helpful to the application skills about vocabulary and grammar, and thus improves other language skills and the comprehensive practical abilities as a whole.

\section{The Current Research}

The Major Data Source. The author takes "college English writing" as the key words, and retrieves the papers in CNKI from 2010-2015. The data are here in table 1:

Table 1. Papers collected in CNKI on college English writing from 2010-2015

\begin{tabular}{|l|l|l|l|l|l|l|}
\hline Year & 2010 & 2011 & 2012 & 2013 & 2014 & 2015 \\
\hline Paper & 96 & 125 & 131 & 124 & 136 & 154 \\
\hline
\end{tabular}

The papers we got for research are mainly from the eight key periodicals on foreign language study, they are: Foreign Language Teaching and Research, Modern Foreign Languages, Journal of PLA University of Foreign Language, Foreign Language World, Foreign Language and Their Teaching, Foreign Languages Research, Foreign Language Research, Foreign Language Education. The number of papers they updated in the CNKI is listed in table 2.

Topics on Writing. Reading papers we researched, we see there are mainly seven kinds of topics, they are: (1) the teaching of writing, including introduction to teaching materials and teaching experience, the setting for writing tasks, the application and experiments of some kinds of methodology, the research for writing teaching online, the writing teaching procedures, the application of relevant writing theories in teaching. [2] (2) The results of writing, including the analysis of discourse and language characteristics in students' compositions, which involve the text analysis, mistakes analysis, comparison analysis, contrastive rhetoric analysis, data analysis. (3) English writing process, we study the students' writing process, including the conception strategies, 
the differences for individual learners and the changing characteristics in different writing stages. (4) The contextual factors for English writing, the discussion of intrinsic and extrinsic influential factors, including native language, the conceptual differences between Chinese and English, cultural factors. (5) Reviews of writing research: the report and analysis of the development and current situation for English writing research at home and abroad. (6) Reader feedback, including teachers' correction and marking, peer editing, self-editing, etc. (7) Writing evaluation, assessment and testing: writing marking, the incredibility and validity of writing topics, and the contract of testing grading criteria for writing at home and abroad. [3]

Table 2. Papers on English writing published on 8 key periodicals 2010-2015

\begin{tabular}{|l|l|l|l|l|l|l|l|}
\hline Key periodicals on foreign language study & 2010 & 2011 & 2012 & 2013 & 2014 & 2015 & Total \\
\hline Foreign Language Teaching and Research & 8 & 10 & 15 & 11 & 12 & 9 & 65 \\
\hline Foreign Language World & 15 & 13 & 12 & 15 & 14 & 12 & 81 \\
\hline Journal of PLA University of Foreign Language & 12 & 17 & 11 & 10 & 18 & 18 & 86 \\
\hline Foreign Language Research & 17 & 14 & 17 & 15 & 15 & 20 & 98 \\
\hline Foreign Language Education & 11 & 15 & 18 & 18 & 20 & 21 & 103 \\
\hline Foreign Language and Their Teaching & 16 & 12 & 20 & 16 & 21 & 25 & 110 \\
\hline Foreign Languages Research & 7 & 20 & 21 & 19 & 16 & 18 & 101 \\
\hline Modern Foreign Languages & 10 & 24 & 17 & 20 & 20 & 31 & 122 \\
\hline Total & 96 & 125 & 131 & 124 & 136 & 154 & 766 \\
\hline
\end{tabular}

\section{The Results and Conclusion}

The Study of Development Trends for College English Writing. First, let's see the studies of the domestic college English writing. Chart 1 shows the published condition of papers on English writing from 2010 to 2015 , see as followed:

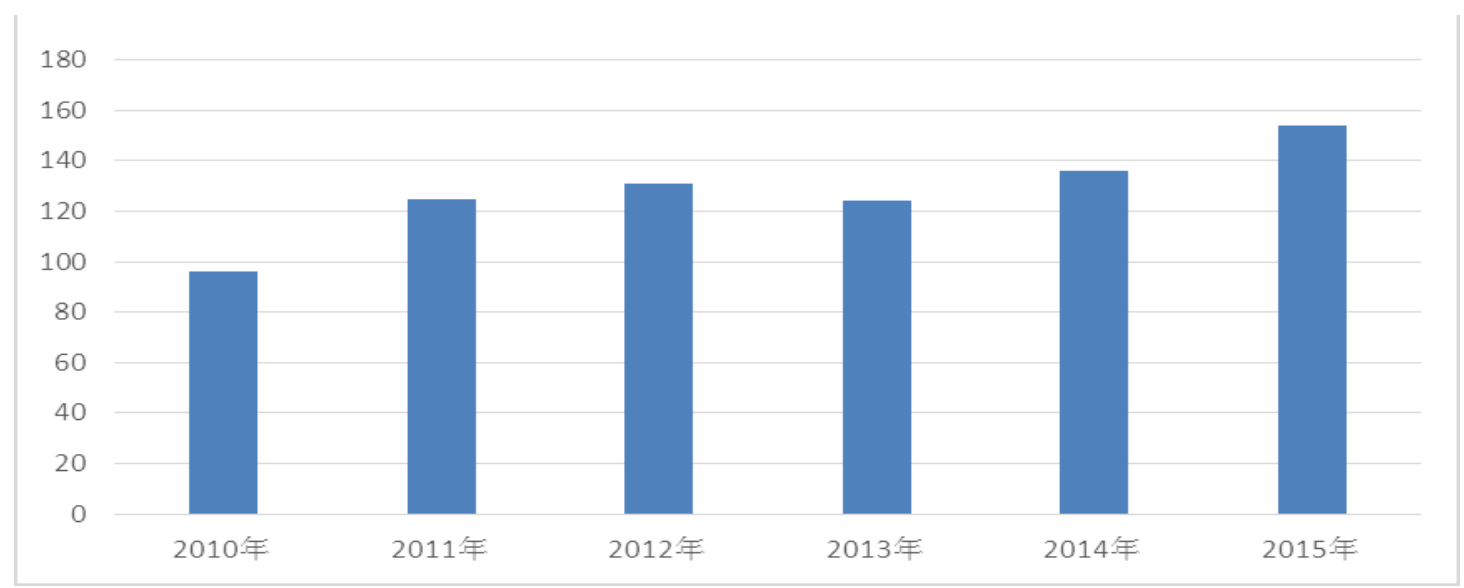

Chart 1. the published condition of papers on English writing 2010-2015

From the chart, we can see that there is an increasing trend for the study of English writing. With the constant exchange activities between China and western countries, all kinds of foreign linguistic teaching materials and linguistic theories are well-known to domestic researchers, and many researchers and experts apply develop the introduction and experiments of these theories. In addition, as the academic circle pay more and more attention to writing, many teachers gradually do their own researches, and try to find the effective methods to improve writing teaching. [4] 
Second, let's see the condition of domestic college writing researches from 2010 to 2015. Table 2 shows the least papers appeared in 2010, and then the number of papers increase gradually. Although it has some ups and downs in the six years, it is still an increase trend as a whole.

Contents Researched in Papers. We study the papers published in the eight key periodicals from 2010 to 2015, and we can find the ranges they involved vary, with the number of topics on teaching the first, and the topics about students' compositions and writing contextual factors are the second and third.

The Developing Trends for the Study of Writing Topics. Table 3 shows the distribution of all kinds of topics of writing published from 2010 to 2015:

Table 3. Topics Distribution 2010-2015

\begin{tabular}{|l|l|l|l|l|}
\hline & $\begin{array}{l}2010-2011 \\
(\%)\end{array}$ & $\begin{array}{l}2012-2013 \\
(\%)\end{array}$ & $\begin{array}{l}2014-2015 \\
(\%)\end{array}$ & $\begin{array}{l}\text { The } \\
\text { percentage in } \\
\text { the whole } \\
\text { papers }\end{array}$ \\
\hline Writing teaching & 55 & 40 & 38 & 45 \\
\hline Writing result & 15 & 19 & 21 & 18 \\
\hline Writing contextual factors & 10 & 21 & 20 & 17 \\
\hline Reader feedback & 3 & 5 & 6 & 4 \\
\hline Reviews of writing research & 5 & 3 & 8 & 6 \\
\hline $\begin{array}{l}\text { Assessment, grading and } \\
\text { testing of writing }\end{array}$ & 8 & 10 & 6 & 7 \\
\hline Writing process & 7 & 2 & 1 & 3 \\
\hline Total & 100 & 100 & 100 & 100 \\
\hline
\end{tabular}

\section{Problems and Suggestions}

Problems. First, let's discuss the research objects. The research objects in those papers are mainly undergraduates and some graduates, seldom involves primary and middle school students, adult education students and online education students. This indicates there is lacking in the range for the research objects, and it needs to expand the range further.

Second, let's talk about the teaching materials. Nowadays, there are only a few studies about writing teaching materials, because college English teaching only takes writing as a subsidiary in class, but not a specialized course. Therefore, students lack the systematic recognition about writing theories. They just imitate, but not create a composition. The further studies about all kinds of teaching materials are needed for designing more authoritative and scientific teaching materials which will be more suitable to Chinese students.

Suggestions. The most important thing is more studies about online English writing are needed. There are more and more papers about teaching of online English writing, from the introduction to the characteristics and advantages of computer and online foreign teaching, to the search for the training models of writing abilities, the class designs and teaching practices in the network environment. [5] Online English teaching has developed into a new teaching model in parallel with the traditional English class teaching, and it is a new channel for improving English writing skills. However, there are still no independent and mature theories and methods which need researchers" further study and discussion, in order to improve learners' English writing skills.

In addition, the studies about enriching writing contents are needed. Nowadays, there are few guidance papers on improving writing contents, and students" lacking writing contents is a problem needed to be further discussed. In the traditional writing teaching process, the model of "outlining" was used more often, but it hinders students' creativities in writing.

Last but not the least, the creative teaching models needed to be researched. Interdisciplinary and 
Multidisciplinary integration will be an innovation point. To strengthen the researches on the combination between English writing teaching and relevant disciplines, such as, linguistics, psychological linguistics, social linguistics, sociology, etc. By studying from different angels, these researches should find the new teaching models which are suitable for Chinese students, and then improve students' writing abilities.

\section{References}

[1] Casanave, C.P. Looking Ahead to More Socio-politically-oriented Case Study Research in L2 Writing Scholarship, J. Journal of Second Language Writing 12 (2003) 89-103.

[2] Du Fuxing, Study Motivation and College English Writing, J. Foreign Language and Their Teaching, 7 (2004): 29-30.

[3] Du Jinbang, The English Teaching from Students' Writing Mistakes, J. Foreign Language Teaching, 2 (2004): 45-46

[4] Ge Shili, Chen Xiaoxiao, The Exploration of Self-editing Grading System for Chinese ELF learners, J. Foreign Language World, 5(2007): 44-48.

[5] Guo Xiaoying, The Design and Practice of Writing Models for College Students under the Environment of Blog, J. Modern Foreign Languages, 3(2009):314-320.

[6] Matsudda, P. K., Process and Post-process: A Discursive History, J. Journal of Second Language Writing 12 (2003) 60-81.

[7] Qin Zhaoxia, The Analysis of the Research Condition for Domestic English College Writing and Development Trend, J. Modern Foreign Languages, 2(2009)195-199.

[8] Cheng Hui, The Analysis of the Research Condition for Domestic English College Writing, J. Journal of Southwest Agricultural University (Social Science Edition), 9(2011), 199-200.

[9] Wang Jinba, The Research for the Dodge in College English Writing, J. Foreign Language Teaching, 3(2010): 56-58.

[10]Zhang Zuocheng, The Exploration of Psychlogical Process of English Writing for Chinese College Students, J. Modern Foreign Language, 1(1995):28-30. 